\title{
Place-Based Education and Heritage Education in in-service teacher training: research on teaching practices in secondary schools in Galicia (NW Spain)
}

Tania Riveiro-Rodríguez (i] ${ }^{1 凶}$, Andrés Domínguez-Almansa ${ }^{1}$, Ramón López Facal (i) ${ }^{1}$ \& Tomás Izquierdo Rus ${ }^{2}$

This paper analyses what occurs when in-service secondary teachers face a new subject, Landscape and Sustainability. Recently implemented in Galicia (NW Spain), this subject has no strong curricular constrictions. It is opened to diverse contents that can be integrated into Social Sciences. It promotes an environmental, social and critical consciousness. The hypothesis was that teachers may present deficiencies when approaching a subject which, due to its characteristics, requires training extending beyond disciplinary knowledge, thus impeding better performance and a greater degree of learning among pupils. The study was organised in three axes: (a) observation of the teaching and learning process in schools $(n=3)$; (b) teacher's conceptions $(n=38)$ on the subject, its context and their pupils' learning; and (c) pupils' reflections $(n=70)$ derived from their learning process. The objectives were: (1) to elaborate a theoretical substantiation for the subject and, in accordance with it, making a critical analysis of the practices observed; (2) to analyse how teachers conceive the subject; and (3) to analyse the pupils' reflections regarding the experience and to what extent they acquire social, civic and/or academic skills. The methodology was qualitative, using in the data analysis a quantitative perspective too. The instruments used were the participant observation, interviews, a closed questionnaire and a semi-opened questionnaire. The results are presented in a descriptive-interpretative way, but also quantitative. It can be advanced that teachers designed the subject in line with Place-Based Education and Heritage Education, but the lack of specific training in those theories ends up blurring their holistic approach in the nearby places. Teachers show similar conceptions about the subject and its teaching process. And the majority of students value positively the methodology used in the initiatives and acquire a socio-critical consciousness.

\footnotetext{
${ }^{1}$ University of Santiago de Compostela, Santiago de Compostela, Spain. ${ }^{2}$ University of Murcia, Murcia, Spain. ${ }^{凶}$ email: tania.riveiro@usc.es
} 


\section{Introduction: a new subject as an opportunity for innovation in the classroom}

he different Autonomous Communities in Spain have leeway to offer optional subjects to complement the curriculum planned by the Ministry of Education. This study analyses what happens in educational experiments framed within the Landscape and Sustainability (L\&S), subject recently introduced in Galicia. It was offered from 2015 to 2016, with $1 \mathrm{~h}$ of class per week for pupils between 12 and 14 years of age (Xunta de Galicia, 2015).

In the teaching of the social sciences there is no possibility of observing a subject from its origins, particularly if it is not subject to great regulatory constraints and to the same pressure of evaluation as the compulsory subjects.

The curricular approach of this subject encourages teachers to rethink their work, using new and participatory strategies focused on landscape and sustainability, contents which were previously only superficially treated in other subjects. An environmental, social and critical approach is promoted, contrary to a traditional approach dominated by decontextualised physical aspects. It introduces new contents and makes it possible to reflect on socioenvironmental justice and the welfare of the community. Furthermore, there are no specific textbooks, thereby empowering the role of the teacher.

The analysis of its teaching and learning process may provide an opportunity to equip teachers with a critical reference point via which their approach can be discussed or redirected. The starting hypothesis is that teachers may present deficiencies when approaching a subject which, due to its characteristics, requires training extending beyond disciplinary knowledge, thus impeding better performance and a greater degree of learning among pupils.

\section{A methodological model for Landscape and Sustainability}

The curriculum of the subject encourages innovation but does not specify how to put it into practice. Therefore, this paper proposes a model based on the surrounding environment and a conception of landscape as an asset of common interest (Augé, 2012), integrating the rights of those who live within it (Rubio and OjedaRivera, 2018) and their empathy as a guarantee of sustainability (Martínez de Pisón, 2010). Thus, landscapes can even gain importance without prior recognition.

It is presented an idea of landscape connected to the concept of place, understood in a holistic manner, as a specific space in which local identities are extremely present (Massey, 1995; Augé, 2012). Its interpretation is both individual and collective, constituting an entity in transformation and a framework of coexistence to which people can feel a sense of belonging in a spatial and social sense, assigning them a signification depending on infinite experiences and their own identities (van Eijck and Roth, 2010; McInerney et al., 2011; Sun et al., 2016). It could be said that places are conceptualised in terms of landscape as they are perceived physical spaces.

Based on this idea, a model for L\&S is proposed (Fig. 1), inspired by its curriculum and incorporating parameters of PlaceBased Education and Heritage Education, as both of these approaches seek a critical reflection of the environment for the acquisition of skills to improve the inhabited place.

The cornerstone of this model is an emotional connection with the local places and landscapes researched by pupils in an interdisciplinary and guided way (Woodhouse and Knapp, 2000; Liceras, 2003, 2016). The link between emotion and reason leads to the acquisition of skills extending beyond academic competence, fostering an appropriation of the environment and, by protecting and looking after it, generating a conscience for a more sustainable ecological and inclusive world.
A rigorous planning of activities with civic objectives is required, preferably in the open air, to foster interaction with the community in order to visualise the interdependence of existence (Theobald, 1997; Woodhouse and Knapp, 2000).

The study is enriched by integrating Heritage Education, reflecting with the pupils on the possible inclusion as heritage of these everyday spaces, stimulating the work of investigating them, valuing them and defending them (Calaf and Fontal, 2006).

This model adopts a socio-critical approach: Transmitted heritage elements are addressed, which are publicly recognised as living documents. However, invisible and hidden places and landscapes are also proposed, even if the memory of them is conflictive, regarding which the pupils must take a stand in debates and reflections. Indeed, it is these scenarios which acquire the greatest educational significance (Domínguez-Almansa and López-Facal, 2016, 2017; Estepa and Martín, 2020).

Local history (Fine-Meyer, 2014) and social memory play a key role (Pinto, 2011). Using documents and memories, the pupils investigate many material and immaterial remains as a link to approaching aspects such as landscape, identity and heritage (Feliu-Torruellas and Hernández Cardona, 2020; Hernández and Castilho, 2006; Pinto and Zarbato, 2017). A "new localism" is proposed (Gruenewald and Smith, 2008) with the aim of promoting the ethics of caring for the environment as a social improvement (Chinnery, 2013), whilst making more explicit connections between globalisation, capitalism, economic exploitation and cultural oppression (McInerney et al., 2011). Pupils participate as interested parties and agents of change in the processes of taking decisions which affect their environment (Morgan, 2012). They can reason and experience excitement and, with this learning, address new landscapes belonging to other social and environmental scenarios, examining in more depth what has been proposed in a similar sense by Cuenca López et al. (2017).

Ultimately, activities based on specific spaces enrich any curriculum (Howley et al., 2011). Thus, Landscape and Sustainability promotes citizenship (Orr, 1994), research, the clarification of values, problem-solving (Sobel, 2004; Gruenewald, 2003;

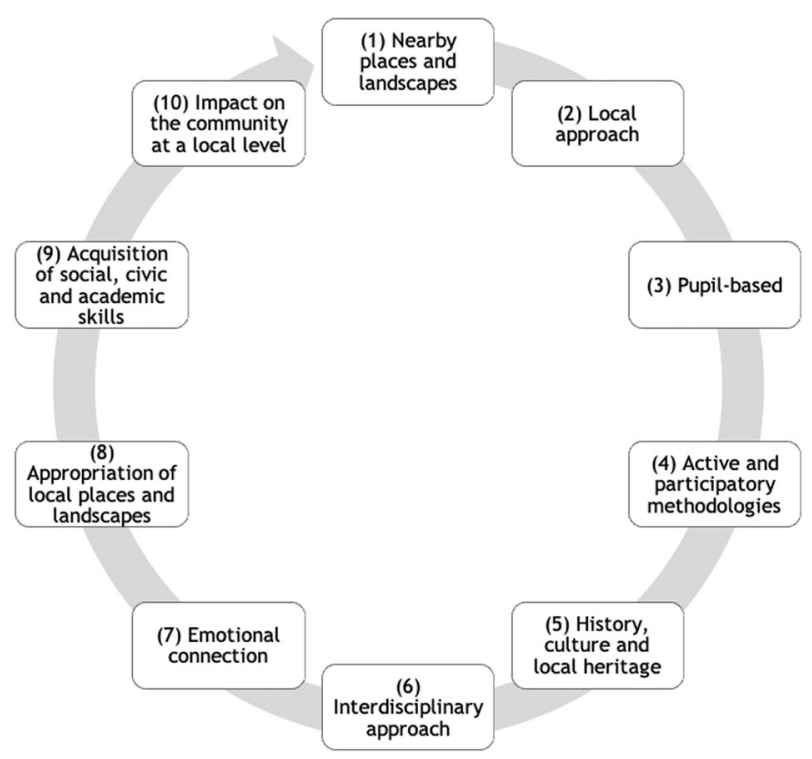

Fig. 1 Teaching proposal for Landscape and Sustainability. Ten dimensions of the proposal, based on Place-Based Education and Heritage Education. 
Knapp, 1996) and decision-taking (Hungerford and Volk, 1990; Knapp, 1996).

Taking this discourse into account, an investigation with three axes is proposed:

a. The observation of the teaching and learning process in three schools.

b. Teachers' conceptions on the subject, its context and their pupils' learning.

c. Pupils reflections derived from their learning process.

From these three axes, three fundamental objectives arise:

1. To elaborate a theoretical substantiation for developing the subject, focusing on Place-Based Education and Heritage Education and, in accordance with this, making a critical analysis of the practices observed.

2. To analyse how teachers conceive the subject and its practical teaching.

3. To identify the evaluation of the participating students regarding the experience and to discover to what extent they have acquired social, civic and/or academic skills.

\section{Method}

This study is framed in the qualitative tradition (Flick, 2009, 2015; Miles and Huberman, 1994; Morse, 2003), although the data analysis did not renounce the incorporation of a quantitative perspective too. It follows the line of educational research: to explain, to understand and to signify (Gibbs, 2007), in this case, the reality of a new subject. It is an inductive and bounded study, with informants from three schools (38 teachers and 70 participating pupils).

It possesses the basic criteria of quality (Flick, 2009): internal validity/credibility, reinforced through an ethical commitment in the fieldwork, the collection of detailed and different type of data, the participants' involvement or control over some parts of the research, and an external and internal audit of the study; external validity/transferability, guaranteed with a brief resemblance to what is being done in 35 out of the 39 schools which teach Landscape and Sustainability, that does allow for transfer to similar educational contexts; reliability, guaranteed with a systemic collection of data; and objectivity, guaranteed with academic integrity from the beginning of the study.

This work employs different empirical materials of a descriptive nature (Denzin and Lincoln, 1994; Mendizábal, 2006): field notes, interview transcripts or teachers' and pupils' responses. Although they are related to the three different central axes of the research (observation of the teaching and learning process; teachers' conceptions; and pupils' reflections), and were analysed independently according to the 10 dimensions of the model proposed in the substantiation (Fig. 1), they are presented in the results in a holistic approach, synthesised in six sections that summarise those 10 dimensions.

Axis 1: Observation of the teaching and learning process. Experiments were carried out in three schools during the 2017/ 2018 academic year. The schools were chosen intentionally according to five criteria: (1) Teachers who were open to systematic observation who had an interest in innovation; (2) The location of the schools was appropriate to the requirements for observation; (3) The idea of landscape was not limited to the physical dimension; (4) The subjects were assumed from different areas, two in the social sciences and one in natural sciences; (5) They encompassed the widest possible range of ages and year groups of pupils (Table 1).

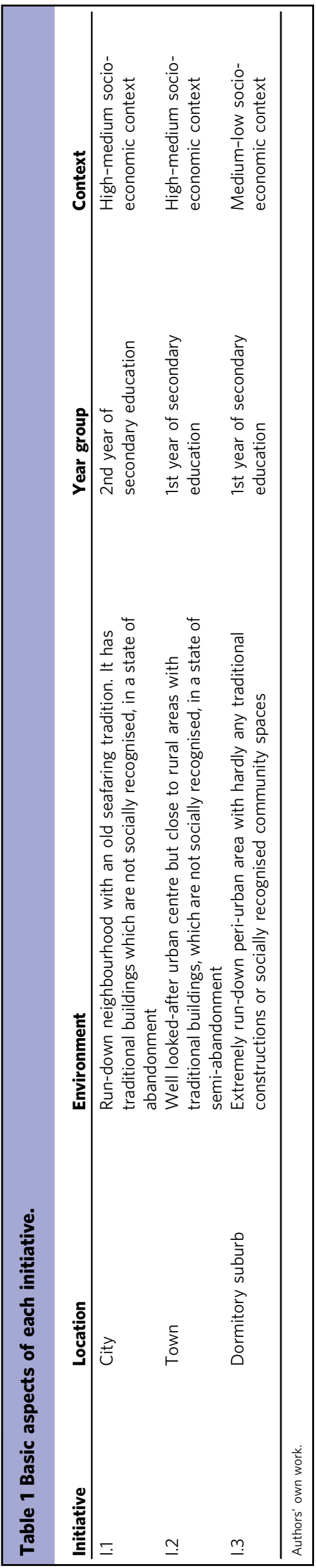


The observation, framed in the participant observation method (Angrosino, 2007), implied regular attendance, which involved more than half of the sessions for each initiative $(\mathrm{I} .1=15$; $\mathrm{I} .2=21$; I. $3=18$ ). Previously, it was created, and externally validated, a form to manually record field notes in the classroom. Those descriptive annotations were computerised and completed periodically (Martínez Miguélez, 2007).

This yielded 74 forms, designed according to a subsequent creation of categories and codes. The information included in the form was related to who took part in the sessions, the role of the teachers, the behaviour of the pupils and the involvement of the researcher; what contents and disciplines were worked on; where they were carried out; when they took place, date; how they were carried out, method, tactics and resources; why they were addressed, objectives, skills and productions derived from them (Martínez Miguélez, 2007).

As a result, the research offers an analytical synthesis of everything observed in relation to the dimensions categorised in the proposal, which has been presented as a benchmark (Fig. 1). The materials were stored in a hermeneutic unit in Atlas.ti. They were categorised into 15 groups of codes with 78 aggregate codes, from which 1034 quotes emerged to describe the experiments as a whole. A comparison and informed numerical ranking were carried out regarding the level of development of the experiments according to the model proposed in Table 2.

Axis 2: Teachers' conceptions. During the observation process, each teacher involved in the three initiatives was interviewed $(2017 / 2018$, I.1 =E1; I.2=E2; I.3=E3). Each of them had a different academic profile (Table 3 ).

Before the interview, three issues were raised regarding the questions to be asked: why they were necessary, what was to be asked and how they would be carried out (Kvale, 2007). As a result, nine semi-open questions were formulated, separated into four sections: (1) a brief professional description; (2) a reflection on innovation, the educational context of the school and participation in previous projects; (3) characteristics of their activity, tactics and evaluation; (4) competences encouraged in pupils and teachers and transfer to society.

\section{Table 2 Levels of development of the dimensions of the model and ranking.}

\section{Level of development}

Fully incorporated

Generically incorporated

Incorporated, albeit superficially

Hardly incorporated but indirectly perceived

Not incorporated

Authors' own work
The audio tracks were transferred to a hermeneutic unit in Atlas.ti. Excerpts were selected and transcribed, either totally or partially. After the first sweep, 213 quotes emerged. These were organised into nine categories or groups of codes, to which 50 codes were added to facilitate the organisation of the content. From the resulting report, 14 ideas were selected, due to their constant repetition, following the establishment of the method of constant comparison. Of these 14 aspects (Table 4), 10 are dealt with in the results (points 5-14).

Inspired by the four sections of the interviews and the ideas that came up from their analysis, an online form was created with 50 closed-ended questions with multiple responses and a subjective scale, some numerical and others evaluative. The intention of this was to facilitate the inclusion in the study of the 39 teachers responsible for teaching this subject in Galicia. The basic data for each school was obtained from the Education Ministry of the Galician regional government. During the 2018/ 2019 academic year, they were contacted on up to three occasions by email or by telephone, in the hope that the digital format would increase the number of participants (Smith et al., 2007). The form was created in the Forms application of Office 365 and 35 teachers replied ( $90 \%$ approx.).

Its aim was to broaden, corroborate or refute the ideas shared by the three teachers interviewed. The majority of the responses were categorical, with some also being dichotomous (Díaz de Rada, 2005). They were classified into 10 blocks (Table 5).

The primary measures of frequency and means were obtained in a spreadsheet.

Axis 3: Pupils' reflections derived from the learning process. The pupils participating in the three initiatives observed were provided with a questionnaire which made it possible to analyse their reflections on the subject, their acquisition of knowledge and the development of a civic conscience (June 2018). This facilitated accessibility to the information without confronting great logistical obstacles (Flick, 2015). Seventy pupils participated $(n=70$ : I.128; I.2, 22; I.3, 20) after finishing the subject and a climate of conscious participation was sought. The questionnaire consisted of 10 questions, in five blocks, and employed photographs of landscapes which were not socially and environmentally sustainable. The aim was to verify whether the pupils made a formal description or whether emotions leading to critical and reasoned reflections were awoken.

An aggregate analysis of the questionnaires was carried out (Díaz de Rada, 2005), they were imported to a hermeneutic unit in Atlas.ti. and were transcribed. This software was chosen considering its potential to organise the data and its capacity to create a structured report. The questionnaires were identified according to the participating pupil and the initiative in which they were included (Es1:I.3; Es21:I.2; Es43:I.1, etc.).

A first level of analysis of the ideas associated to each question made it possible to create 94 codes (Table 6).

\section{Table 3 Profile of the teachers interviewed.}

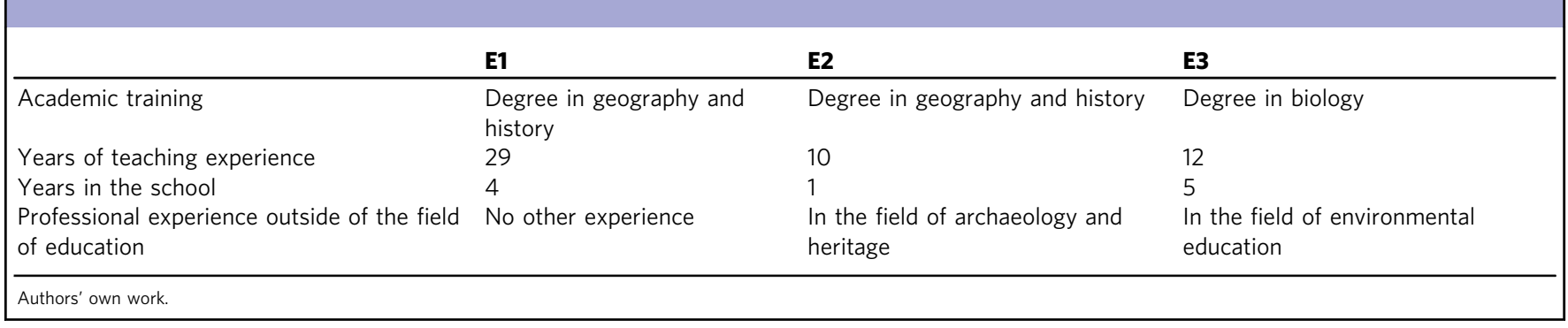




\section{Table 4 Common blocks of the interviews of E1, E2 and E3.}

1. Positive evaluation of an open curriculum

2. Positive evaluation of the involvement of the school community

3. Association of professional stability with teaching innovation

4. Association of control over teachers with the lack of teaching innovation

5. Evaluation of teaching innovation as a form of professional learning

6. Association of teaching innovation with a greater degree of professional well-being

7. Association of the subject with the development of critical thinking among pupils

8. Association of the subject with the development of social skills among pupils

9. Association of the landscape with immaterial elements

10. Association of sustainability with the environment and social aspects

11. Association of landscape with heritage

12. Positive evaluation of transferring teaching outcomes to the local community

13. Association of critical teaching with the necessary social support

14. Association of the subject to different objectives

Authors' own work

\section{Table 5 Blocks and variables ascribed.}

\section{Block}

Professional characteristics of the teacher

Personal and professional experience in L\&S

Context of the school

General characteristics of the initiative of L\&S

Response of the pupils to the initiative and relationship with the environment

Reflection on methodological strategies

Reflection on a critical approach

Reflection on obstacles to innovation

Reflection on possible transfers of the initiative to society

Final observations

\section{Description of the variables}

Sex; academic training; years of teaching experience; years in the school; academic year and department in which he/she teaches

Prior and future interest in teaching the subject; present experience in L\&S; possible improvements; importance conferred upon the subject

Province; physical and cultural characteristics of the context; educational line of the school Type of learning sought; alignment to curriculum; objectives, sources and resources; type of evaluation and tools

Pupils response to the initiative; type of identification of the pupils with the local environment

Evaluation of the active role of the pupils; learning by discovery; active methodologies; collaborative work

Evaluation of the fostering of a critical conscience; social justice; environmental justice; heritage; social and civic attitudes

Evaluation of the importance for innovation of the support of the school management, the teaching staff, teacher commitment, administration and the benefits of innovation among pupils and among teachers from a professional point of view

Repercussions of L\&S in the local area; possible raising of awareness of the everyday landscape; resignification of people; collaborative learning; resignification of visible and invisible heritage; the importance of social and environmental sustainability

A space for addressing any other aspect

Authors' own work.

Tables of frequency and co-occurrence were created and consolidated with direct quotes obtained from the responses, with each of the three initiatives represented. The information made it possible to refute or confirm both the data collected in the observation and in the teachers' responses.

\section{Results}

The results of the research are presented taking into account these three fundamental axes: observation, teachers' conceptions and reception among the pupils. They are integrated in a framework of six thematic blocks (TB) based on the 10 dimensions of the teaching model which has been proposed for the successful teaching of Landscape and Sustainability (Fig. 1).

TB.1. The use of places, nearby landscapes and a local approach

Axis 1: Observation of the teaching and learning process. Work is carried out on places and landscapes with a focus on the local area.
In I.1, the physical transformations and sustainability of the urban framework in the area in which the school is located are investigated. In this area, property speculation has damaged the traditional buildings of everyday life and even places of natural value. Furthermore, many aspects of popular culture have been forgotten.

In I.2, local landscapes are investigated, integrating material and immaterial elements in the process of abandonment, applying concepts such as landscape sustainability and heritage.

In I.3, there is no research and its approach is more regional than local. The inhabited space is not examined in detail as it is considered that the inexistence of places with recognised heritage value hinders work in a relatively run-down urban area. As an alternative, certain representative landscapes of Galicia are proposed.

Applying the criteria of level of development, each initiative acquires the ranking as shown in Table 7.

Axis 2: Teachers' conceptions. Both the teachers of the experiments observed, and the 35 participants gave value to prior research on the surrounding environment. They highlight its role in providing them 


\section{Table 6 List of questions and codes.}

Block 1: Reflection on the initiative

Block 2: Reflection on the experience of the collaborative work

Block 3: Importance given to the subject and differences with respect to other subjects

Block 4: Definition of the contents which structure landscape, sustainability and heritage

Block 5: Definition of landscapes in which the acquisition of a civic conscience and academic competence is are demonstrated
Question 1: 14 codes in total

Did you like the way in which you were taught Landscape and Sustainability?

Did it seem different to other subjects?

How did you feel?

Question 2: 13 codes in total

What was most interesting for you?

Do you think that anything could be improved?

Question 3: 11 codes in total

Had you worked in a group before?

What did you think of the experience?

Question 4: 12 codes in total

Was the subject Landscape and Sustainability important for you? Would you recommend it to other classmates?

Question 5: 4 codes in total

What do you think was the most important thing you learned in this subject?

Question 6: 6 codes in total

What is a landscape for you?

Question 7: 2 codes in total

What do you think sustainability means?

Question 8: 7 codes in total

Do you think that a landscape can form part of your heritage? Or, in other words, do you think that there are landscapes which are important to you? Why

important to you? Why

Explain this image (a):

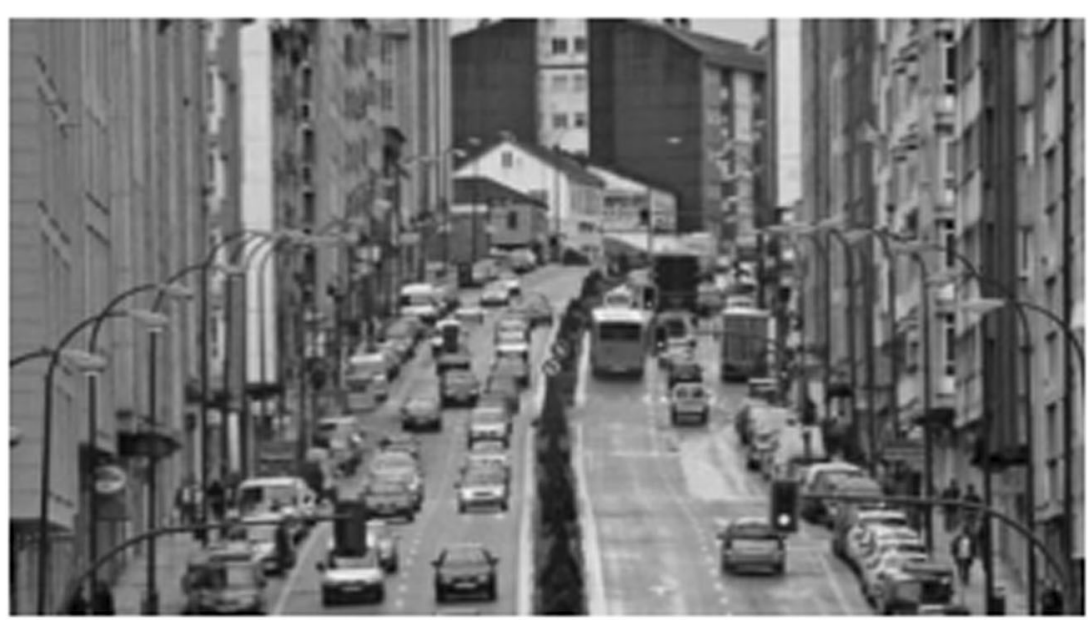

Explain this image (b):

Critical description; Uncritical description; Elements of environmental sustainability; Elements of social sustainability

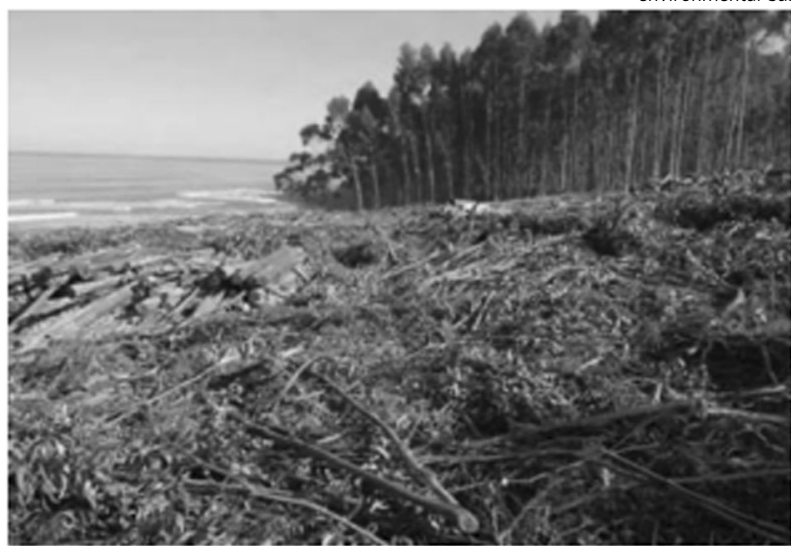




\section{Table 6 (continued)}

Explain this image (c):

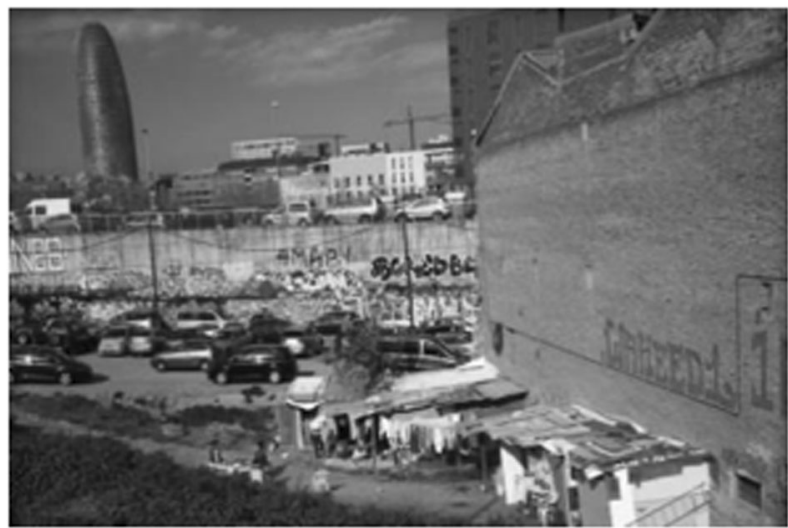

Question 10

Observe the following images. Do you think there may be any relationship between them? $(\mathrm{d} / \mathrm{e})$
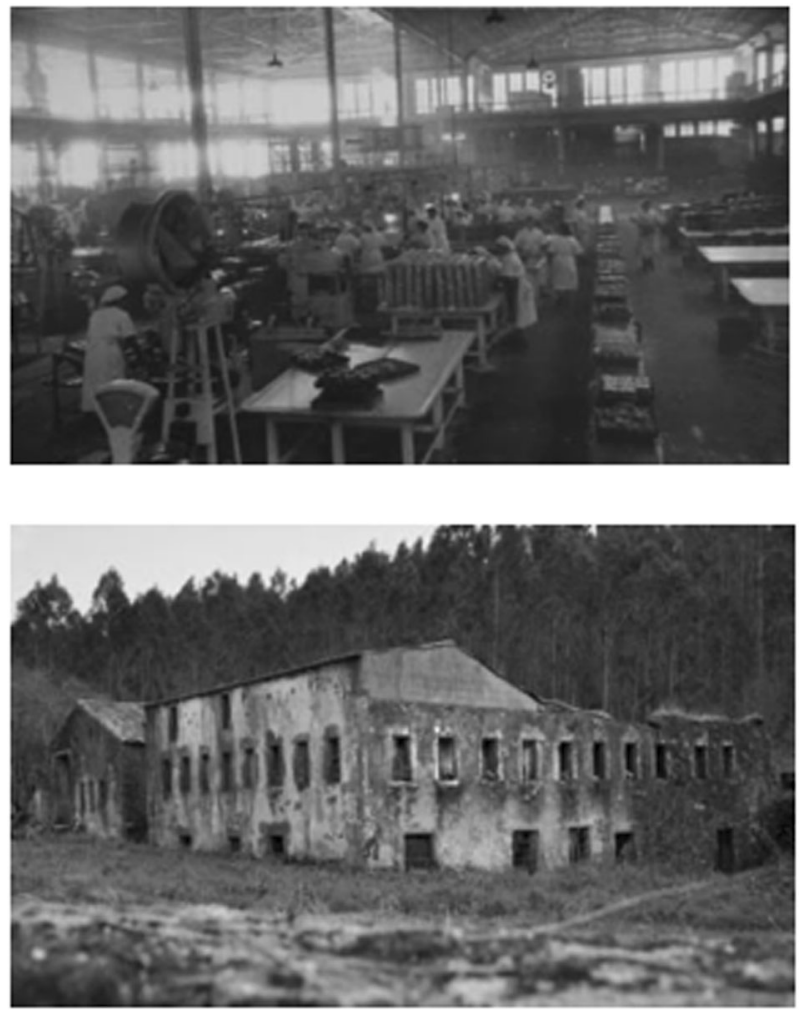

Would you do anything with the building in ruins?

Would renovate it; Would knock it down; Employment operation; Public service operation; Convert it into a museum; Leisurewelfare operation; Environmental operation; Would knock it down due to economic reasons; Would knock it down due to lack of value

Authors' own work

with new disciplinary knowledge (mean: 4.23), and, to a lesser extent, a greater degree of professional well-being (mean: 3.94). Those interviewed expressed the following opinions: “(...) I learn a lot from this type of project (...) Thanks to these projects, I immerse myself in the local history" (E1:66); “(...) It brings me peace ... I am doing a better job” (E2:58); “(...) it's always necessary to look for something which excites you in order to add to what has been done" (E1:68); "(...) it allows me to escape from traditional subjects ... it breaks up my routine” (E3:38).

Axis 3: Pupils' reflections. The pupils valued the subject positively, projecting it onto other experiences $(n=60 / 70)$. Many of them highlighted their interest due to learning about familiar places: "It is good in order to have an understanding of aspects which normally go unnoticed" (Es33:I.2) (Table 8).

TB.2. The use of pupil-based active and participatory methodologies

Axis 1: Observation of the teaching and learning process. I.2 and I. 3 conferred a key role upon the pupils. I.1 is more intermittent, prioritising a programmed discourse by the teacher.

I.2 strictly adheres to a learning model guided by discovery. It puts into practice research methodology of a collaborative nature. 


\begin{tabular}{|llr|}
\hline \multicolumn{2}{|l|}{$\begin{array}{l}\text { Table } 7 \text { Dimensions of the model (TB.1) and the level of } \\
\text { development. }\end{array}$} & Ranking \\
Dimensions & 1.1 & 5 \\
\hline L\&S: local places and landscapes & 1.2 & 5 \\
& 1.3 & 2 \\
Local approach & 1.1 & 5 \\
& 1.2 & 5 \\
& 1.3 & 2 \\
\hline Authors' own work. & & \\
\hline
\end{tabular}

Table 8 Pupils' view of the subject/initiative.

\begin{tabular}{lll} 
Initiative & Positive view & Negative view \\
\hline I.1 & 24 & 3 \\
I.2 & 16 & 4 \\
I.3 & 19 & 1 \\
Total & 59 & 8 \\
\hline Authors' own work. & & \\
\hline
\end{tabular}

\begin{tabular}{|c|c|c|}
\hline \multirow{2}{*}{$\frac{\text { Dimensions }}{\text { Pupil-based }}$} & \multicolumn{2}{|c|}{ Ranking } \\
\hline & 1.1 & 4 \\
\hline & 1.2 & 5 \\
\hline & 1.3 & 5 \\
\hline \multirow[t]{3}{*}{ Active and participatory methodologies } & 1.1 & 4 \\
\hline & 1.2 & 5 \\
\hline & 1.3 & 5 \\
\hline
\end{tabular}

The research is included in a database which serves as a virtual museum for use within the school. A tour, led by the pupils, is made around the places researched.

I. 3 does not follow one teaching model in particular but makes use of different participatory strategies. Unlike the others, there is discontinuity among the topics dealt with. It employs collaborative strategies for carrying out the three projects for each term, which are pupil-led.

I.1 proposes learning based on modest projects on the local geography and history. It attempts to foster collaborative learning, although the excess of compartmentalisation of the topics proposed to each group favours individual work. The pupils' activity is organised around two teaching units, created by the teacher on a website.

Applying the criteria of level of development (Table 2), each initiative acquires the ranking as shown in Table 9.

Axis 2: Teachers' conceptions. The three teachers interviewed and the 35 surveyed expressed great interest in offering active and participatory experiments. They associate this with the involvement of the pupils (mean: 4.40) and learning of a critical nature (mean: 4.06): "This subject provides formation (...) I am a citizen and I begin to have a grounded opinion regarding how land can be managed" (E1:64); "(...) I think that the more active the
Table 10 Pupils' experience of collaborative work in the initiative.

\begin{tabular}{llll} 
Initiative & Positive & Could be improved & Negative \\
\hline I.1 & 21 & 5 & 2 \\
I.2 & 16 & 2 & 4 \\
I.3 & 11 & 4 & 5 \\
Total & 48 & 11 & 11 \\
\hline Authors' own work. & & \\
\hline
\end{tabular}

activities, the more possibilities we have of motivating them and exercising that transformative capacity" (E2:54).

Axis 3: Pupils' reflections. The majority of the pupils reacted positively to the use of collaborative strategies $(n=48 / 70)$. They highlight aspects such as harmony, team spirit and learning: “(...) it really promotes harmony" (Es1:I.3); "It's good because we learn to work in groups, which is necessary for the future" (Es36:I.2); "We learned to coordinate ourselves" (Es44:I.1); "(...) it was an experience in which I learned a lot (...)” (Es18:I.3). However, the high percentage of non-positive evaluations in I.3 should be mentioned (Table 10).

TB.3. The use of history, culture and local heritage with an interdisciplinary approach

Axis 1: Observation of the teaching and learning process. I.1 and I.2 interweave history, culture and local heritage. In I.3 it is fragile and irregular. As far as interdisciplinarity is concerned, it is only accredited in I.2. I.1 and I.3 would be transdisciplinary.

I.1, dominated by geography and history and with a transdisciplinary perspective, deals with the sustainability of territory from the perspective of consumption, resources, the human footprint and well-being. The pupils research the landscape via physical, social, historical and cultural elements and attention is paid to the possibilities of recovery in the neighbourhood. No joint work with teachers of other subjects is undertaken.

I.2 is open to interdisciplinarity, seeking collaboration with other subjects, such as biology (the flora of the place) and physical education (dances associated to a place). A balance is sought between social and natural sciences, transferring this to the pupils' research on a landscape which is studied from multiple angles, including actions for greater environmental and social sustainability. It makes it possible for conflictive issues relating to the past or the present, or both at the same time, to emerge.

I.3 does not include work with other teachers. It employs a traditional perspective of physical geography and environmental education. The research on landscapes is synthesised in their location, characteristic elements, ecology, cartographic representation and anthropisation on a basic level. Aspects such as their historical, cultural and social sediment are not paid attention to or are developed in a superficial manner.

Applying the criteria of the level of development (Table 2), each initiative acquires the ranking as shown in Table 11.

Axis 2: Teachers' conceptions. Teachers E1 and E2 value incorporating tangible and intangible elements, identifying people as something inseparable from the landscape. E3, like some of the 35 participants surveyed, does not see this link clearly, although the majority do (mean: 3.83): "We study the landscape taking into account both natural and human aspects ... we work with material and immaterial aspects, which are also extremely important, although they are not tangible" (E1:7); "The proverbs, 


\begin{tabular}{|lll|}
$\begin{array}{l}\text { Table } 11 \text { Dimensions of the model (TB.3) and level of } \\
\text { development for each initiative. }\end{array}$ \\
Dimensions & Ranking \\
\hline History, culture and local heritage & 1.1 & 5 \\
& 1.2 & 5 \\
Interdisciplinary approach & 1.3 & 2 \\
& 1.1 & 4 \\
& 1.2 & 5 \\
\hline Authors' own work. & 1.3 & 3 \\
\hline
\end{tabular}

\begin{tabular}{|c|c|c|c|c|}
\hline Initiative & Important & $\begin{array}{l}\text { Not } \\
\text { important }\end{array}$ & Recommends it & $\begin{array}{l}\text { Does not } \\
\text { recommend it }\end{array}$ \\
\hline 1.1 & 16 & 11 & 16 & 11 \\
\hline 1.2 & 15 & 6 & 15 & 6 \\
\hline 1.3 & 17 & 3 & 18 & 2 \\
\hline Total & 48 & 20 & 50 & 19 \\
\hline
\end{tabular}

riddles, feelings, senses, experiences, gastronomy ... games, celebrations" (E2:8).

Axis 3: Pupils' reflections. They highlight the importance of "Knowing about the customs of the past" (Es32:I.2); “... knowing who we are and where we came from" (Es50:I.1); "The changes in the landscape over time and factors which modified them" (Es12: I.3); "that dropping litter on the ground, polluting, does not only affect nature, but also affects ourselves" (Es2:I.3); “(...) that things can change, we can do better and we have to look after the environment" (Es10:I.3); "valuing everything we have and recognising how the landscape has drastically changed" (Es57: I.1). Thus, the majority state that the subject is important $(n=48$ / $70)$ and recommend it $(n=50 / 70)$, without making particular reference to the importance of interdisciplinarity. It is in I.3 that the relevance of this learning is highlighted most (Table 12).

TB.4. Fostering an emotional connection which favours processes of appropriation

Axis 1: Observation of the teaching and learning process. The three experiments began with a weak emotional and cognitive connection with the surrounding area. The teachers attempted to strengthen this connection so that the pupils could appropriate their places and familiar landscapes.

I.1 puts forward the idea of the quality of places and landscapes as a right. Hence, the idea of contributing towards the recovery of urban spaces by way of active proposals. However, although interest in local places among the pupils was noted when reflecting on current problems which affect their sustainability, the proposals did not lead to action.

I.2 includes the memory of family members and local people as an element of reference, leading to an interest in and a connection with places which the pupils assume as their own.

I.3, which had many students of foreign origin, sought to create a link with a context which was difficult to accept, tending to avoid run-down areas. No evidence can be seen of the
Table 13 Dimensions of the model (TB.4) and the level of development for each initiative.

\begin{tabular}{lll} 
Dimensions & Ranking & \\
\hline Emotional connection & 1.1 & 3 \\
& 1.2 & 4 \\
Appropriation of local places and landscapes & 1.3 & 2 \\
& 1.1 & 3 \\
& 1.2 & 4 \\
Authors' own work. & 1.3 & 2 \\
\hline
\end{tabular}

appropriation of places and landscapes without a greater general awareness regarding the environmental problem.

Applying the criteria of the level of development (Table 2), each initiative acquired the ranking as shown in Table 13.

Axis 2: Teachers' conceptions. The teachers interviewed and the participants surveyed are convinced that the subject favours an awareness of the landscape and its protection (mean: 4.31). However, the level of agreement is lower with regard to its usefulness in signifying absent and forgotten groups (mean: 3.54): "(...) they develop an awareness of heritage (...)" (E1:59-60); "(...) they were much more aware of the value of their landscape. They made active proposals of how to look after it and improve it (...) If they say that there should not be eucalyptus, or that there should be re-population, we are not going to be able to carry it out, but they make these evaluations (...)" (E2:40); “(..) older people or social groups such as those repressed by the dictatorship or the Civil War, because we work on negative and undesired heritage, it should not be preserved because it is an example, but rather in order not to repeat it (...) regarding migration, women (...)" (E2:43-44).

The vast majority accept the incorporation of the heritage dimension (mean: 4.23), associating it clearly to the study of the landscape (mean: 4.60) and believing that it strengthens the link with everyday places (mean: 4.69). E1 and E2 conceive it more openly than E3: "What we attempt to do is to work on the landscape, identifying positive heritage aspects and, in this way, defining and contributing towards a more sustainable landscape" (E2:5).

Axis 3: Pupils' reflections. No clear relationship between emotions and landscape can be appreciated $(n=6 / 70)$, as cognitive elements prevail in the pupils' identifications. Furthermore, the emotional component is always expressed positively, never critically: "A place for enjoyment" (Es17:I.3); "Something extremely relevant for me" (Es31:I.2); "It is a personal view of the flora and fauna which surrounds us. This view is influenced by emotions, memories ..." (Es64:I.1) (Table 14).

\section{TB.5. Fostering of social, civic and academic skills}

Axis 1: Observation of the teaching and learning process. The three initiatives promote civic skills. They broaden environmental awareness, reflecting critically on changes and continuities in rundown places and on individual and collective responsibility.

The social inequalities latent in places and landscapes are also addressed (more clearly in I.1 and in I.2), along with the reasons for the neglect of cultural manifestations which characterised many places.

In addition, academic advancement is expected, beginning with understanding and describing concepts such as landscape and 


\section{Table 14 Pupils who relate landscape with emotions.}

\begin{tabular}{ll} 
Initiative & Landscape-emotions \\
\hline I.1 & 3 \\
1.2 & 1 \\
I.3 & 2 \\
Total & 6 \\
\hline Authors' own work. & \\
\hline
\end{tabular}

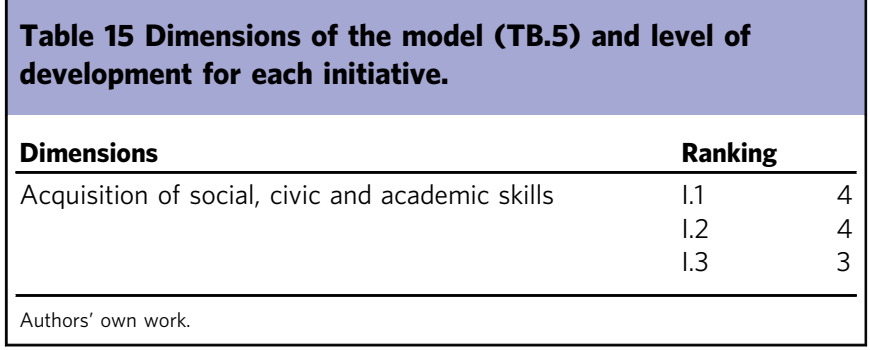

sustainability, and all the cognitive framework which they imply. This is better addressed in I.1 and I.2 than in I.3.

Applying the criteria of the level of development (Table 2), each initiative acquired the ranking as shown in Table 15.

Axis 2: Teachers' conceptions. The teachers observed and those surveyed believe that it is important to foster civic consciousness (mean: 4.14), accepting their responsibility in achieving this (mean: 4.43). However, they appeal to the involvement of society as a whole: " $(. .$.$) none of this is of any use if it is not accompanied$ by social morality to go along with the discourse" (E1:63).

They clearly associate the need to study landscape with its environmental sustainability (mean: 4.20 ). However, their level of agreement is weakened when referring to the importance of social sustainability (mean: 3.46), which is extremely evident in E1 and E2: "(...) it is difficult to break with this inertia of speaking of sustainability only from the environmental point of view. (...) [social sustainability] is a concept to which we are not accustomed (...)" (E2:40-41).

Axis 3: Pupils' reflections. a. On the concept of landscape: a broad majority adopts stereotypical positions of different kinds. Three points of view are predominant as shown in Table 16.

A mediatised view is imposed by idealised nature in which human action is excluded: "An area which is not polluted and everything in it is nature (...) everything is as it was created, and nobody has reformed it" (Es3:I.3).

The geographical perspective is similar to the previous view, having an impact on the classification of elements delimited in space: "A geographical space which combines biotic, abiotic and anthropic elements" (Es42:I.2).

To a lesser extent, an association is made with the human race and its social, cultural and environmental impact: "A place which combines fauna, flora and things made by humankind but which can be good as well as bad" (Es23:I.2); "It is any type of space, be it urban, natural, beautiful, ugly..." (Es45:I.1); "They are geographical spaces (...) with moral and cultural aspects" (Es53:I.1).

b. Regarding sustainability: environmental consciousness is mentioned, albeit divested of a social conscience: "(...) treating the environment around us correctly" (Es12:I.3); "A lifestyle which is respectful towards the environment" (Es34:I.2);
Table 16 Type of perspective of landscape for each initiative.

\begin{tabular}{|lccl} 
Initiative & Idealised nature & Geographical & $\begin{array}{l}\text { Humanised and/or } \\
\text { emotional }\end{array}$ \\
\hline I.1 & 12 & 8 & 8 \\
I.2 & 7 & 12 & 2 \\
I.3 & 10 & 7 & 5 \\
Total & 29 & 27 & 15 \\
\hline Authors' own work. & & \\
\hline
\end{tabular}

Table 17 Description of sustainability.

\begin{tabular}{ll} 
Idea of sustainability & Associated quotes \\
\hline Environmental sustainability & 55 \\
Social sustainability & 3 \\
No answer & 12 \\
\hline Authors' own work. & \\
\hline
\end{tabular}

Table 18 Relationship of landscape and heritage.

\begin{tabular}{ll} 
Association of landscape and heritage & Associated quotes \\
\hline Does not associate landscape and heritage & 12 \\
Associates landscape and heritage & 58 \\
\hline Authors' own work. &
\end{tabular}

"Something sustainable is that which does not damage the environment" (Es47:I.1). Only three people related social wellbeing with the idea of landscape sustainability: "This sustains something, in this case the correct use of resources for the wellbeing of future generations" (Es52:I.1); "Handling natural resources in such a way that it is possible to improve the wellbeing of the population" (Es61: I.1) (Table 17).

c. Regarding heritage: the majority consider that landscapes and everyday places can form part of their heritage $(n=58 / 70)$ (Table 18).

When they associate landscape and heritage, they establish five different values (Table 19).

The most repeated association links heritage and personal memory, by way of positive memories regarding specific places: "(...) they may have a sentimental value, such as your grandparents house, the playground you went to when you were a child" (Es3: I.3); “(...) there are many landscapes which are important to me because they remind me of something or of someone" (Es25: I.2); “(...) the landscapes I see every day are part of my life and my routine" (Es50: I.1).

After the emotional aspect, others highlight the natural value associated to the quality of life as a value which shapes landscape and heritage: "For me, it is important because it helps there to be less pollution (...)" (Es2:I.3); "The landscape is part of my heritage because I enjoy being in nature and this improves my quality of life" (Es47:I.1).

To a lesser extent, it is associated with identity: “(...) there are landscapes of great touristic and cultural interest, which are extremely rich for all Galicians" (Es21:I.2); “(...) in Galicia we have a landscape which identifies us. Therefore, it is important for me because it forms part of my identity and history" (Es64:I.1); 
Table 19 Value given to landscape.

\begin{tabular}{llllll} 
Initiative & Emotional value & Natural value & Identity value & Aesthetic value & Historical value \\
\hline I.1 & 7 & 5 & 5 & 4 & 2 \\
I.2 & 8 & 2 & 4 & 1 & 2 \\
I.3 & 11 & 5 & - & 6 & - \\
Total & 26 & 12 & 9 & & 4 \\
\hline Authors' own work. & & &
\end{tabular}

\begin{tabular}{|c|c|c|}
\hline Initiative & Renovation & Destruction \\
\hline 1.1 & 13 & 9 \\
\hline 1.2 & 14 & 4 \\
\hline 1.3 & 12 & 5 \\
\hline Total & 40 & 18 \\
\hline
\end{tabular}

with aesthetics: “(..) you can always find something beautiful to look at" (Es56:I.1); and with history: “(..) there are ancient landscapes which tell us things about the past (...)" (Es69:I.1); "(...) they form part of the history of our city and I believe it is important to preserve this heritage" (Es59:I.1).

d. Regarding civic commitment: they show an interest in rundown places.Considering an old ruined factory, the majority would renovate it $(n=40 / 70)$, mainly for public and/or social reasons $(n=24 / 40)$ (Table 20$)$.

They would reconvert the building for educational purposes or to accommodate excluded people: "A school or a place for refugees" (Es29:I.2); "I would rebuild it and send the homeless there" (Es44:I.1); in order to guarantee jobs for the unemployed: "I would improve it to give jobs to those who cannot work (...)" (Es17:I.3); "It could be reformed to (...) generate more opportunities for employment" (Es23:I.2); to preserve natural elements in the surrounding area: "I would rebuild it because then we would not damage more places where there can be a lot of trees" (Es28:I.2); to convert it into a museum: "Make it a place for tourists to visit, but with someone to explain its history" (Es40: I.2); “(...) what I would do would be to renovate it and convert it into a type of museum, because I believe this factory is part of our past and I would not feel good about destroying it" (Es64:I.1); "I would not let it fall down, I would rebuild it and create a museum, recreating the old factory with its machines (...) we must not let our heritage fall down" (Es59:I.1); to improve the urban space: "I would rebuild it to convert it into a recreational site for public and environmental leisure" (Es33:I.2); or to promote leisure and consumption: "I would restore it to make it into a shopping centre with great shops and a swimming pool" (Es3:I.3).

When faced with great imbalances in landscapes, a third of the participants identified them and offered solutions $(n=23 / 70)$ : “(...) We need to use public transport more" (Es7:I.3-imageA); "This landscape represents our brutality towards our nature, we tear down trees which give us life in order to have more money (...)” (Es10:I.3-imageB); “(...) In one corner there are people who live in houses made of broken materials. This makes us aware that we have to be more human and ecological" (Es13:I.3-imageC).

\section{TB.6. Transfers and impact on the local community}

Axis 1: Observation of the teaching and learning process. The three initiatives aim to transfer their results to the local community,
Table 21 Dimensions of the model (TB.6) and level of development for each initiative.

\begin{tabular}{lll} 
Dimensions & Ranking & \\
\hline Impact on the community on a local level & 1.1 & 2 \\
& 1.2 & 4 \\
& 1.3 & 2 \\
\hline Authors' own work. & & \\
\hline
\end{tabular}

although this does not come to pass, with the exception of I.2. However, I.1 and I.3 generate an environmental awareness in the pupils which may have an impact in the future, although this is difficult to define.

In I.2 the impact is perceived by way of an educational excursion, designed and organised by the pupils, the open exhibitions held in the school and the festival of traditional dance at the end of the academic year. This demonstrates an intergenerational dialogue which incorporates memory, places and landscapes.

Applying the criteria of the level of development (Table 2), each initiative acquired the ranking as shown in Table 21.

Axis 2: Teachers' conceptions. Importance is given to the fact of transferring the results of their teaching activity to the community (mean: 4.14), even though many of these desires do not become reality: "(...) making that inventory, an analysis and a proposal for improvement (...) my intention is for that proposal to reach the school's management, the school council and the local authorities" (E3:29); “This year I wanted to make a proposal to the local council of what we conclude ... The routes that they propose, for example, posting them on the council's website (...) these are little things that the pupils can see" (E2:40); "I hope that, as a result of all this, we can organise educational meetings about the city ... that would be a dream for me" (E1:31).

The formulae for transfer differ among the three teachers interviewed when specifying their objectives: “(..) I would like it if, when someone mentions Galicia, they knew where to locate the four provinces the most important geographical features and natural spaces and some of the most relevant cities (...) and also that they would value them. That is where identity would be created (...) firstly regarding this place and then Galicia" (E3:25-26); "(...) to make them see that this place changed in a certain way but that it could have changed in another way if there had been an awareness of heritage, of ancient, not old, things" (E1:33); "I think that the general objective is for them to know the landscape which surrounds them and to take decisions about it, which they can contribute as active citizens ... for them to be creators of and participants in heritage" (E2:43). These differences were also perceived in the 35 teachers surveyed. The main objective of practically half of them was to achieve a critical reflection on the environment in order to correct its deterioration in the future $(n=17 / 35)$. A little more than a third would like to 


\begin{tabular}{|c|c|c|c|c|}
\hline Initiative & $\begin{array}{l}\begin{array}{l}\text { Local } \\
\text { environment }\end{array} \\
\end{array}$ & Method & $\begin{array}{l}\text { Landscape and } \\
\text { environment }\end{array}$ & $\begin{array}{l}\text { Educationa } \\
\text { excursions }\end{array}$ \\
\hline 1.1 & 12 & 5 & 4 & - \\
\hline 1.2 & 5 & 9 & 2 & 5 \\
\hline 1.3 & 4 & 5 & 5 & 6 \\
\hline Total & 21 & 19 & 11 & 11 \\
\hline
\end{tabular}

be identified as agents of change in the present $(n=13 / 35)$, whereas less than a fifth proposed an understanding, evaluation and identification with Galician landscapes $(n=5 / 35)$.

Axis 3: Pupils' reflections. The transfer of results to the community is difficult to measure in the pupils' responses. However, it is significant that a third considered that the most important aspect of their learning in the subject was their increase in awareness of the environment and its social and cultural heritage, highlighting the possibility of interacting with other agents in their community ( $n=21 / 70)$ : "The most interesting thing for me was to ask my grandmother about it" (Es53:I.1); "What was most interesting for me was to discover exactly what the neighbourhood was like before, its heritage" (Es61:I.1).

This awareness brought about a willingness to care for the environment $(n=11 / 70)$ : “ $\ldots$ we must respect the landscape more and we cannot build wherever we want" (Es10:I.3); "When we saw the consequences of our polluting acts on the earth (...)" (Es46:I.1). This also constitutes a new perspective on the environment, with which new relationships could be established $(n=11 / 70)$ : "The most interesting thing about this topic was going on an excursion together and learning things about landscape, and the museums, which were very interesting (...)" (Es19:I.3) (Table 22).

\section{Discussion}

The process of observation in the classroom, the analysis of how the teachers conceive their teaching practice and the way in which this is projected onto the pupils makes it possible to evaluate the teachers' state of training in order to undertake the educational challenge supposed by the new subject of Landscape and Sustainability. Below are listed the strengths and main training needs which have been detected.

Prior strengths. The flexibility in the curriculum enables teachers to adopt decisions coherent with what they understand to be quality teaching (Riveiro-Rodríguez et al., 2020). In this regard, they demonstrate a relatively solid knowledge of the context in which they work. They do not act as burnt-out professionals, a common occurrence in secondary education (Pena Garrido and Extremera Pacheco, 2012). Rather, they take the advantage of using the subject as an exciting experiment, thereby favouring a better learning atmosphere (Laudadío and Mazzitelli, 2019).

An effort and capacity to carry out research and design integral activities on the local environment is noticed, which is well received by the pupils, who value learning about places which give meaning to their everyday reality. To a large extent, these activities are intuitively adjusted to many of the parameters of Place-Based Education and Heritage Education.

A good level of training in constructivist methods and participatory strategies is demonstrated. These are implemented in the classroom as catalysts of a more transformative learning process (Genç, 2016; Miralles et al., 2017) and a greater level of cohesion and inclusion (De Espinosa et al., 2019). Furthermore, they are carried out correctly by the pupils.

There is a reliance on multidisciplinarity, which guarantees a better integration of history, culture and heritage. This benefits the holistic study of local landscapes, approached from a double perspective; social justice and environmental education, as found in I.1 and I.2, which are based on the social sciences.

The skilled use of different strategies is confirmed, which tend to strengthen the cognitive and emotional connection of the pupils with the place where they live, which becomes a space of awareness and intergenerational dialogue, as can be observed in I.1 and I.2.

Learning contexts are generated in which the pupils develop social and civic attitudes, contributing solutions, fundamentally for environmental imbalances and run-down places.

Critical positions and attitudes are guaranteed, in line with a civic and social, as well as a critical and active, education (Fernández-Vega and Cárcamo-Vásquez, 2017; SantistebanFernánez et al., 2020), at least, with an indirect impact on society.

The subject is taken to be a learning framework for pupils who are more competent and more committed towards what has been learned, with the belief that this will be translated into an educational improvement and, also, into social progress (Alexandre, 2016; Anderson, 2015).

Needs detected. The coincident trend between the projects and what was expressed by the participating teachers demonstrates a common viewpoint with regard to the subject and its objectives. However, the flexibility in its curriculum, the lack of specific guidelines and of specific training demonstrates deficiencies in the planning and implementation of the teaching activities, which can be observed, above all, in the pupils' learning.

In spite of the capacity for designing educational proposals in line with Place-Based Education, the non-existent theoretical baggage received in this regard makes it difficult for teachers to carry out more precise work and to achieve objectives relating to the environment, particularly in run-down contexts. Including this educational trend in the processes of teacher training, disseminating experiments in different places and with approaches more in line with the model presented, would favour greater productivity in the projects.

Although the dominant pedagogical culture is left behind (Gruenewald, 2003; Israel, 2012) and an alternative process of learning is fostered, which is open to methodologies of a collaborative nature, pupils do not always receive it positively, coinciding with the strategies which do not introduce a greater socio-critical significance to the study of the environment.

It seems necessary for there to be better training in the design and implementation of not only transdisciplinary, but also interdisciplinary projects in which teachers from different fields collaborate, as this has been proved to be extremely useful in the study of landscape (Gómez Trigueros, 2018), due to its capacity to create links with the local environment. A greater degree of job stability for teachers in schools could also be a determining factor in this type of activities.

More training in heritage and in the possibilities of memory as a link between rational and emotional aspects and places is necessary (Domínguez-Almansa and López-Facal, 2016, 2017). Not all teachers appear to be aware of its potential and pupils, when addressing the issue of the meaning of landscape or heritage, ignore this question, giving preference to purely 
cognitive aspects. However, this does not occur when they evaluate and seek alternatives for run-down places, leading to a dichotomy between what they believe that they should respond on an intellectual level and when they act in the face of real facts. Although the activities are oriented to a discourse which insists on social and environmental aspects, a need for focusing more on contents in the social sphere is shown, given that a representation almost exclusively associating landscape and environment is prevalent among pupils.

Although the aim is to transfer results to the local community, this is hardly noted in a direct way. It is intended that the pupils demand participation in the environment, but when projecting this objective towards the future, and not the present, it becomes more difficult for them to feel like real agents of change. In this regard, teacher training programmes should orient teachers towards contextualising their practical teaching in a better way, which has been shown to be extremely beneficial, especially in places with problems of inclusion, social cohesion and deficient environmental development (Rodríguez Sosa et al., 2017).

\section{Conclusions}

This research proposes and presents practical teaching which combines Place-Based Education and Heritage Education, from a holistic and critical perspective, as an optimal approach for the subject Landscape and Sustainability. Bearing in mind that the intentions and aspirations of teachers point towards a coincidence with this model, it would be pertinent to be able to integrate it into a training process which is needed in order to approach with more guarantees and even satisfaction a subject, which teachers claim to take on with enthusiasm and civic vocation.

Although this study has shown a confluence among teachers when this subject and the opportunities it brings are considered, in future research it would be interesting to broaden the observation process to a greater number of experiments. In this way, it could be verified whether the information gathered here is representative of all projects put into action in the subject of Landscape and Sustainability, in the sense that the transformative discourse is, both on an educational and social level, accompanied by coherent action, as the teachers observed are attempting to do.

It remains to be seen whether the concerns and reflections shared by the teachers participating in this study will be maintained by those who will teach the subject in future years, or if, on the contrary, these criteria are altered.

It would also be desirable to investigate an aspect which seems particularly relevant: the fact that the teachers stated that in other subjects they adopt a different, more traditional, approach to that which they feel able to embrace in the subject studied here. This would lead to an examination of the routes teachers take to relegating or abandoning their vocation as innovators (Riveiro-Rodríguez et al., 2020).

With regard to the pupils, who are the best instrument for measuring the scope of any teaching activity, an abundance of enriching reflections are observed, even though they are somewhat incomplete as they are materialised in responses to open questions or to images which generate problems. However, although it is true that their reflections indicate that there is a margin of improvement in their learning process, it is extremely interesting to note that they show a great degree of satisfaction with practices far removed from those of the dominant routines, bringing them closer to the local environment.

In this regard, as has been noted, working on landscape and places in which processes of heritagisation can be opened up can be highlighted as an urgent need, by appealing to memory and to social recognition
The 70 pupils who took part in this study are a conservative number for understanding the learning process in Landscape and Sustainability. Evidently, this number should be increased in future research.

Therefore, it is hoped that this subject can continue to be monitored. It would be interesting to know whether, over the course of time, it becomes standardised and more hermetic or whether its teachers continue to consider it an exciting experiment which they teach of their own free will and even that, based on this premise, training can be fostered which addresses the needs presented in this research.

It is extremely desirable that projects such as those presented and analysed here have a future projection, given that it has been proved that they can have a capacity to bring about environmental and social benefits via the formation and civic awareness of the pupils.

If, by way of a quality teaching action, pupils come to understand the local landscape, become aware of the need to care for it and, from this perspective, transcend the frontiers of the local environment, it is possible that it can serve to promote attitudes which extend far beyond the school context and are prolonged in time.

\section{Data availability}

The datasets generated during and/or analysed during the current study are not publicly available due to the anonymity of participants and schools, but are available from the corresponding author on reasonable request.

Received: 28 September 2020; Accepted: 7 December 2020; Published online: 20 January 2021

\section{References}

Alexandre F (2016) The standardization of geography teacher's practices: a journey to self-sustainability and professional identity development. Int Res Geogr Environ Educ 25(2):166-188

Anderson D (2015) The nature and influence of teacher beliefs and knowledge on the science teaching practice of three generalist New Zealand primary teachers. Res Sci Educ 45(3):395-423

Angrosino M (2007) Doing etnographic and observational research. Sage, Londres Augé M (2012) Naturaleza, Cultura y Paisaje. Conferencia. Rev Colomb Antropol 49(2):223-238

Calaf R, Fontal O (2006) Miradas al patrimonio. Trea, Gijón

Chinnery A (2013) Caring for the past: on relationality and historical consciousness. Eth Educ 8(3):253-262

Cuenca López JM, Estepa Giménez J, Martín Cáceres M (2017) Heritage, education, identity and citizenship. Teachers and text-books in compulsory education. Rev Educ 375:136-159

De Espinosa LPL, Muñoz Y, Seijo MJCT (2019) Implicaciones de la formación del profesorado en aprendizaje cooperativo para la educación inclusiva. Profesorado. Revista de currículum y formación del profesorado 23(4):128-151

Denzin NK, Lincoln YS (1994) Introduction: entering the field of qualitative research. In: Denzin NK, Lincoln YS (Eds.) Handbook of qualitative research, 3rd edn. Sage Publications, Thousand Oaks

Díaz de Rada V (2005). Manual de trabajo de campo en la encuesta (presencial y telefónica). Cuadernos Metodológicos, 36. Centro de Investigaciones Sociológicas, Madrid.

Domínguez-Almansa A, López-Facal R (2016a) Invisible landscapes-heritage in conflict: memories of the Spanish Civil War: elementary education and teacher training. Int J Hist Learn Teach Res 14(1):55-66

Domínguez-Almansa A, López-Facal R (2016b) Memoria histórica, patrimonio y formación del profesorado de educación primaria. In: Puche SM, Molina NL, Gil. TM eds Identidad, ciudadanía y patrimonio. Educación histórica para el siglo XXI. Ediciones Trea, Asturias, pp. 71-86

Domínguez-Almansa A, López-Facal R (2017) Patrimonios en conflicto, competencias cívicas y formación profesional en educación primaria. Rev Educ 375:86-109

Estepa Giménez J, Martín Cáceres M (2020) Heritage in conflict: a way to educate in a critical and participative citizenship. In: Delgado Algarra EJ, Cuenca López JM (eds.) Handbook of research on citizenship and heritage education. IGI Global, Hershey, pp. 43-55 
Feliu-Torruellas M, Hernández Cardona FX (2020) The Spanish Civil War in the Classrooms: working for citizenship education. In: Delgado Algarra EJ, Cuenca López JM (eds.) Handbook of research on citizenship and heritage education. IGI Global, Hershey, pp. 429-448

Fernández-Vega JP, Cárcamo-Vásquez H (2017) Noción de ciudadanía en estudiantes de pedagogía. Rev Electrón Educ 21(2):1-28

Fine-Meyer R (2014) Engendering power and legitimation: giving teachers the tools to claim a place for history education in their schools. In: Sandwell R, von Heyking A eds Becoming a history teacher. Sustaining practices in historical thinking and knowing. University of Toronto Press, Toronto, pp. 291-302

Flick U (2009) An introduction to qualitative research. Sage, London

Flick U (2015) Designing qualitative research. Sage, London

Gibbs G (2007) Analyzing qualitative data. Sage, Thousand Oaks

Genç M (2016) An evaluation of the cooperative learning process by sixth-grade students. Res Educ 95(1):19-32

Gómez Trigueros IM (2018) La interdisciplinariedad y las tecnologías como nuevas estrategias para el aprendizaje del paisaje. Cuad Geogr 57(3):77-96

Gruenewald DA (2003) The best of both worlds: a critical pedagogy of place. Educ Res 32(4):3-12

Gruenewald DA, Smith GA (2008) Introduction: making room for the local. In: Gruenewald DA, Smith GA (Eds.) Place-based education in the global age: local diversity. Lawrence Erlbaum Associates, New York, pp. 13-23

Hernández Aracena R, Castilho Pereira IA (2006) Educación patrimonial en Facao, Mato Grosso: una propuesta sobre patrimonio, identidad, educación y desarrollo local. Rev Int Desenvolv Local 8(13):19-27

Howley A, Howley M, Camper C, Perko H (2011) Place-based education at Island Community School. J Environ Educ 42(4):216-236

Hungerford HR, Volk TL (1990) Changing learner behavior through environmental education. J Environ Educ 21:8-22

Israel AL (2012) Putting geography education into place: what geography educators can learn from place-based education, and vice versa. J Geogr 111(2):76-81

Knapp C (1996) Just beyond the classroom. ERIC Press, Charleston

Kvale S (2007) Doing Interviews. Sage, Thousand Oaks

Laudadío J, Mazzitelli C (2019) Formación del profesorado: Estilos de enseñanza y habilidades emocionales. Rev Mex Investig Educ 24(82):853-869

Liceras Ruiz A (2003). Observar e Interpretar el Paisaje. Estrategias didácticas. Grupo Editorial Universitario.

Liceras Ruiz A (2016) La Geografía, el paisaje y los mapas. In: Ruiz AL, Sánchez GR (Coords.) Didáctica de las Ciencias Sociales. Fundamentos, contextos y propuestas. Pirámide, Madrid.

Martínez Miguélez M (2007) La investigación cualitativa etnográfica en educación. Manual teórico-práctico. Eduforma, Seville

McInerney P, Smyth J, Down B (2011) 'Coming to a place near you?' The politics and possibilities of a critical pedagogy of place-based education. Asia-Pacif J Teacher Educ 39(1):3-16

Martínez de Pisón E (2010) Saber ver el paisaje. Estud Geogr 71(269):395-414

Massey D (1995) Places and their pasts. Hist Workshop J 39(1):182-192

Mendizábal N (2006). Los componentes del diseño flexible en la investigación cualitativa. In: Vasilachis de Gialdino I (Coord.), Estrategias de investigación cualitativa. Gedisa, Barcelona, pp. 65-106.

Miles MB, Huberman AM (1994) An expanded sourcebook. Qualitative data analysis. Sage, London

Miralles P, Gómez C, Rodríguez PR (2017) Patrimonio, competencias históricas y metodologías activas de aprendizaje. Un análisis de las opiniones de los docentes en formación en España e Inglaterra. Estud Pedagóg 43(4):161-184

Morgan A (2012) Inclusive place-based education for "Just Sustainability". Int J Incl Educ 16(5-6):627-642

Morse JM (2003) Asuntos críticos en los métodos de investigación cualitativa. Publicaciones Universidad de Alicante, Alicante

Orr DW (1994) Earth in mind: on education, environment, and the human prospect. Island Press, Washington

Pena Garrido M, Extremera Pacheco N (2012) Inteligencia emocional percibida en el profesorado de Primaria y su relación con los niveles de burnout e ilusión por el trabajo (engagement). Rev Educ 359:604-627

Pinto H (2011) Educação histórica e patrimonial: conceções de alunos e professores sobre o passado em espaços do presente. Doctoral thesis in Education Sciences. University of Minho, Portugal

Pinto H, Zarbato J (2017) Construyendo un aprendizaje significativo a través del patrimonio local: prácticas de Educación Patrimonial en Portugal y Brasil. Estud Pedagóg 43(4):203-227
Riveiro-Rodríguez T, Domínguez-Almansa A, López-Facal R (2020) Teachers representations about the teaching-learning process of the subject landscape and sustainability in secondary classrooms in Galicia, Spain. Rev Electrón Educ 24(3):1-23

Rodríguez Sosa J, Lingan SK, Hernández RM, Alhuay Quispe J (2017) Experiencia de innovación en desarrollo profesional docente. Interdisciplinaria 34 (2):407-423

Rubio Tenor M, Ojeda-Rivera JF (2018) Paisaje y paisajismo: realidad compleja y diálogos discursivos. Bol Asoc Geógr Esp 78:245-269

Santisteban-Fernánez A, González-Monfort N, Pagès-Blanch J (2020) Critical citizenship education and heritage education. In: Delgado Algarra EJ, Cuenca López JM (eds.) Handbook of research on citizenship and heritage education. IGI Global, Hershey, pp. 26-42

Smith A, Jolene S, Dillman D, Leah MC (2007). Improving response quality in ListStyle Open-Ended questions in a web and telephone surveys. Presentation at the annual conference of the American Association for Public Opinion Research-AAPOR, Anaheim.

Sobel D (2004) Place-based education: connecting classrooms and communities. The Orion Society.

Sun Y, Chan RCK, Chen H (2016) Learning with geographical sensitivity: placebased education and its praxis. Prof Geogr 68(4):574-583

Theobald P (1997) Teaching the commons: place, pride, and the renewal of community. Westview Press, Boulder

van Eijck M, Roth WM (2010) Towards a chronotopic theory of "place" in placebased education. Cult Stud Sci Educ 5:869-898

Woodhouse JL, Knapp CE (2000). Place-based curriculum and instruction: outdoor and environmental education approaches. ERIC Digest. https://eric.ed.gov/? $\mathrm{id}=\mathrm{ED} 448012$

Xunta de Galicia (2015). ORDEN del 15 de julio de 2015, por la que se establece la relación de materias de libre configuración autonómica de elección para los centros docentes en las etapas de educación secundaria obligatoria y bachillerato, y se regula su currículo y su oferta. Diario Oficial de Galicia, 21 de julio de 2015, núm. 136, pp. 30316-30319.

\section{Acknowledgements}

This study forms part of the project "The emotional dimension and controversial issues in teacher training" (PGC2018-094491-B-C31), funded by the Spanish Ministry of Economy and Competitiveness and co-funded by the ERDF of the European Union.

\section{Competing interests}

The authors declare no competing interests.

\section{Additional information}

Correspondence and requests for materials should be addressed to T.R.-R.

Reprints and permission information is available at http://www.nature.com/reprints

Publisher's note Springer Nature remains neutral with regard to jurisdictional claims in published maps and institutional affiliations.

Open Access This article is licensed under a Creative Commons Attribution 4.0 International License, which permits use, sharing, adaptation, distribution and reproduction in any medium or format, as long as you give appropriate credit to the original author(s) and the source, provide a link to the Creative Commons license, and indicate if changes were made. The images or other third party material in this article are included in the article's Creative Commons license, unless indicated otherwise in a credit line to the material. If material is not included in the article's Creative Commons license and your intended use is not permitted by statutory regulation or exceeds the permitted use, you will need to obtain permission directly from the copyright holder. To view a copy of this license, visit http://creativecommons.org/ licenses/by/4.0/

(C) The Author(s) 2021 